\title{
SISTEM REKOMENDASI DASHBOARD DESA CERDAS MENGGUNAKAN COLLABORATIVE FILTERING
}

\author{
Zahir Zainuddin ${ }^{1}$, Nursaida Yusuf ${ }^{2}$, Yuyun $^{3}$ \\ ${ }^{1}$ Departemen Teknik Informatika, Fakultas Teknik, Universitas Hasanuddin, Indonesia \\ ${ }^{2,3}$ Magister Sistem Komputer, STMIK Handayani Makassar, Indonesia \\ Email: ${ }^{1}$ zainuddinzahir@gmail.com, ${ }^{2}$ nursaida.margam1630@gmail.com, ${ }^{3}$ yuyuneabula@handayani.ac.id
}

(Naskah masuk: 17 Desember 2021, diterima untuk diterbitkan: 30 Desember 2021)

\begin{abstract}
Abstrak
Desa Maregam merupkan salah satu desa yang berada di Kota Tidore Kepulauan yang memiliki berbagai macam produk buatan masyarakat setempat seperti Hito, Sarabati dan Tenun Puta Dino. Tetapi dalam mempromosikan produknya masih secara konvesional sehingga itu yang terjadi kendala pemasarannya. Salah satu solusi dari strategi pemasaran tersebut adalah dengan membangun sistem Dashboard Desa Cerdas. Penelitian ini bertujuan untuk membantu masyarakat, UMKM dan BUMDes dalam memanfaatkan media digital berbasis Android agar produk-produknya dapat dikenal banyak orang dan menjadi salah satu inovasi dalam mempromosikan dan memasarkan produk-produk lokal yang ada di Desa Maregam. Metode yang digunakan Colaborative Filltering bekerja dengan cara menjumlahkan rating atau pilihan dari suatu produk. Menentukan profil pola pengguna dengan melihat history rating yang diberikan pengguna. Dan menghasilkan suatau rekomendasi baru berdasarkan perbandingan antar pengguna. Penelitian ini menghasilkan sistem Dashboard Desa Cerdas Berbasis Android yang di uji menggunakan metode pengujian User Acceptance testing dan blackbox testing dengan hasil $100 \%$ berhasil.
\end{abstract}

Kata kunci: Colaborative Filltering, Android, Media digital, Desa Cerdas, BUMDes

\section{SYSTEM OF SMART VILLAGE DASHBOARD RECOMENDATION USING COLLABORATION FILTERING}

\begin{abstract}
Maregam Village is one of the villages in the Tidore Islands City which has various kinds of products made by local people such as Hito, Sarabati and Puta Dino Weaving. However, in promoting their products, they are still conventionally so that is the problem with marketing. One solution to this marketing strategy is to build a Smart Village Dashboard system. This study aims to help the community, MSMEs and BUMDes in utilizing Androidbased digital media so that their products can be known by many people and become one of the innovations in promoting and marketing local products in Maregam Village. The method used by Collaborative Filltering works by adding up the ratings or choices of a product. Determine the user's pattern profile by looking at the rating history given by the user. And generate a new recommendation based on comparisons between users. This study resulted in an Android-Based Smart Village Dashboard system which was tested using the User Acceptance testing and blackbox testing methods with $100 \%$ successful results.
\end{abstract}

Keywords: Collaborative Filtering, Android, Digital Media, Smart Village, BUMDes

\section{PENDAHULUAN}

Desa memegang peranan penting dalam menopang perekonomian bangsa. Pengembangan desa merupakan bagian dari rangkaian pembangunan nasional[1]. Beragam aktivitas dilakukan pemerintah untuk percepatan pembangunan wilayah pedesaan namun hasilnya masih belum signikan dalam meningkatkan kesejahteraan masyarakat. Desa-desa di Indonesia khususnya di desa Maregam memiliki ciri khas dan permasalahan tersendiri yaitu kendala ekonomi yang menjadi masalah bagi tercapainya pembangunan desa[2].

Salah satu cara dalam mengatasi permasalahan yang ada yaitu dengan pengelolaan secara cerdas (smart), yaitu dilakukan lebih cepat dibandingkan pertumbuhan masalah itu sendiri. Solusi cerdas yang dimaksud adalah dengan mengimplementasikan desa cerdas[3]. 
Desa cerdas didefinisikan sebagai daerah dan masyarkat pedesaan yang dibangun diatas kekuatan dan aset mereka sendiri, serta pada saat yang sama terdapat usaha untuk mengembnangkan peluang baru dimana jaringan baik tradisional maupun baru dan pelayanan ditingkatkan melalui teknologi digital, telekomonikasi, inovasi dan pengetahuan yang lebih baik[4].

Desa Maregam merupakan sebuah desa kecil yang masuk dalam wilayah administratif Kecamatan Tidore Selatan, Propinsi Maluku Utara. Letak geografis Desa Maregam berbatasan dengan pulau Tidore dan Pulau Moti. Desa yang memiliki 567 jiwa ini terkenal dengan desa Gerabah. Desa yang mayoritas warganya memiliki tingkat kratifitas yang sangat tinggi dan telah banyak menghasilkan produk kerajinan gerabah dan ini telah menjadi mata pencharian utama warga setempat. Di Desa Maregam sendiri untuk mengelola produk kerajinan gerabahmaupun produk kreatifitas lainnya telah dinaungi oleh Badan Usaha Milik Desa (BUMDes)[5].

Badan Usaha Milik Desa (BUMDes) adalah badan usaha yang di buat untuk peningkatan kesejahteraan masyarkat. Selain itu, BUMDEs juga diperuntukan untuk mempercepat pembangunan pedesaan melalui pendampingan dalam upaya mempercepat pembangunan perekonomian daerah yang efektif, mandiri dan kokoh[6].

BUMDes di Desa Maregam ini telah diimplementasikan pada pendanaan UMKM. Beberapa penduduk memiliki UMKM (Usaha Mikro Kecil Menengah). UMKM merupakan salah satu usaha produktif yang sering dilakukan oleh sebagian besar kalangan usaha masyarkat indonesia[4]. Pemasaran Hasil Usaha Kecil dan Menengah (UMKM) di desa Maregam ini dinilai masih kurang optimal karena dalam transaksi pembelian produk diharuskan mendatangi tempat penjualan untuk melakukan transaksi jual beli secara langsung dengan penjual. Selain itu untuk pemasaran masih dilkukan dalam skala lokal yaitu dalam cakupan wilayah Maluku Utara, sehingga produk-produk belum dikenal secara luas. Beberapa produk yang dipasarkan di desa Maregam masih kesulitan dalam mencari pelanggan. Untuk itu diperlukan suatu sistem yang menyarankan informasi yang berguna atau menduga apa yang dilakukan pelanggan untuk mencapai tujuannya, misalnya memilih produk tertentu. Penentuan untuk mencari pelanggan dapat dilakukan dengan cara menerapkan metode Colaborative Filltering. Untuk menghasilkan sebuah sistem yang dapat merekomendasi produk kepada pelanggan. Dengan adanya sistem rekomendasi, desa berupaya untuk memberikan informasi produk lebih mudah kepada pelanggan untuk memilih produk yang sedang dicari maupun direkomendasikan oleh sistem[7].

\section{METODE PENELITIAN}

Dalam penelitian ini bersumber dari data primer dan sekunder. Data Primer bersumber dari kantor desa dan kepala BUMDes Desa Maregam Kecamatan Tidore Selatan Kota Tidore Kepulauan, dimana terdapat data produk yang kemudian dikelola oleh UMKM dan BUMDes. Data sekunder dilakukan dilakukan dengan.

Sistem ini dirancang untuk membangun dashboard yang memudahkan desa untuk memasarkan produk yang dimiliki. Sistem yang dikembangkan untuk memberikan informasi produk lebih mudah kepada user untuk memilih produk yang sedang dicari maupun direkomendasikan oleh sistem[8][9]. Alur dari penelitian ditunjukkan pada Gambar 1.

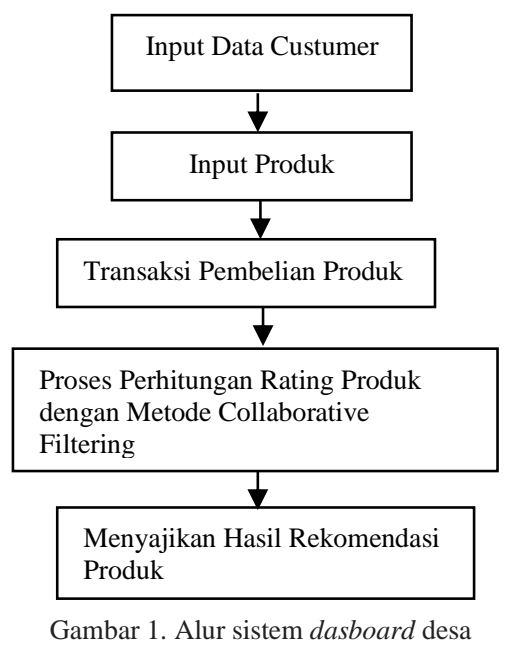

Berikut deskripsi dari setiap bagian gambar alur sistem tersebut :

a. Adapun perancangan dari sistem ini dimulai dengan penginputan data costumer melalui aplikasi android oleh custumer.

b. Penginputan data produk-produk yang ada di UMKM Desa Maregam.

c. Trasaksi pembelian produk yang dilakukan oleh custumer, beserta pemberian rating terhadap produk yang telah dibeli.

d. Proses perhitungan rating produk dengan menggunakan metode collaborative filtering terhadap pemberian rating oleh costumer yang telah melakukan transaksi pembelian produk.

e. Menyajikan hasil rekomendasi produk yang direkomendasikan kepada custumer.

Metode pemrosesan sistem rekomendasi menggunakan algoritma Colaborative Filtering. Schafer membagi algoritma ini kedalam dua kelas yaitu algoritma probabilistik dan non-probabilistik. Sementara itu algoritma non-probabilstik lebih kepada analisis kedekatan yang disebut nearest neighbour yang dibagi menjadi dua kelas yaitu berbasir user dan berbasis item[10].

Algoritma user-based nearest neighbour memanfaatkan olah statistika dalam mengidenitikasi sekumpulan pengguna yang mempunyai kemiripan (neighbour). Setelah sekumpulan tetangga terbentuk, 
sistem menggunakan algoritma yang berbeda untuk menggabungkan kesukaan neighbours untuk menghasilkan perediksi atau rekomendasi N-teratas untuk aktive user[11].

Algoritma item-based collaborative filtering adalah metode rekomendasi yang didasari atas adanya kesamaan rating terhadap suatu produk yang user beli. Dari tingkat kesamaan produk, kemudian dibagi dengan parameter kebutuhan pelanggan untuk memperoleh nilai kegunaan produk. Produk yang memiliki nilai kegunaan tertinggilah yang kemudian dijadikan rekomendasi[12].

Dibawah ini merupakan diagram pemrosesan sistem rekomendasi menggunakan item based Collaborative Filtering.

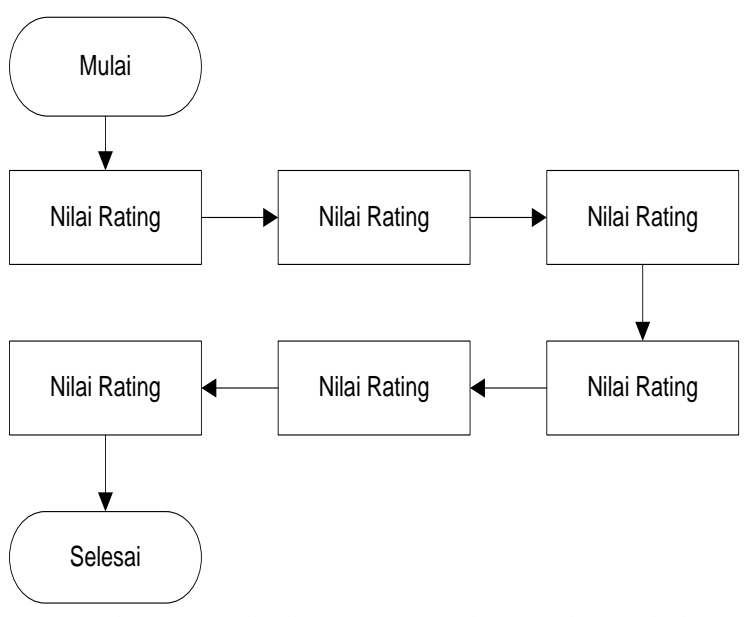

Gambar 2. Metode dan Rancangan Sistem Rekomendasi

Pertama-tama rating dari setiap pengguna dikumpulkan. Kemudian nilai rating di transformasi dalam bentuk matriks. Nilai setiap rating kemudian dihitung average nya untuk menemukan nilai kemiripan (similarity) dari setiap item. Dasar perhitungan kemiripan pada collaborative filtering berbasis item yaitu dua buah item $\mathrm{i}$ dan $\mathrm{j}$ adalah dengan mencari user mana saja yang telah memberi rating pada item $\mathrm{i}$ dan $\mathrm{j}$ kemudian dihitung similaritynya[13].

Metode pearson correlation based similarity merupakan metode perhitungan berbasis korelasi dengan mengukur seberapa besar hubungan linear antara dua variabel. Koefisien korelasi dengan pearson distribusi probabilitas bernilia mean 0 dan varians $(0,10)$. Metode pearson corelation-based similarity dihitung dengan persamaan berikut[14].

$\operatorname{sim}(k, l)=\frac{\sum_{\mathrm{u}=1}^{\mathrm{m}}\left(R_{u, k}-\overline{R_{k}}\right)\left(R_{u, l}-\overline{R_{1}}\right)}{\sqrt{\sum_{u=1}^{m}\left(R_{u, k}-\overline{R_{k}}\right)} \sqrt[2]{\sum_{u=l}^{m}\left(R_{u, l}-\overline{R_{1}}\right)^{2}}}(1)$

Dimana sim merupakan similarity, $k$ dan $l$ adalah item, $R$ adalah rating dan $u$ adalah user yang akan memberikan rating. Sementara itu untuk mengakumulasi kesamaan pengguna dalam membeli item, pendekatan Cosine similarity digunakan. Pendekatan ini mempunyak kelemahan pada skala rating antara berbagai pengguna. Jika dibandingkan dengan cosine similarity, kedua metode tersebut sangat berbeda. Untuk mengatsi kelemahan yang ada cosine similarity mengatasi kelemahan yang ada dengan mengan mengusulkan Adjusted Cosine Similarity dapat ditunjukkan oleh persamaan[15].

$$
\operatorname{sim}(k, l)=\frac{\sum_{\mathrm{u}=1}^{\mathrm{m}}\left(R_{u, k}-\overline{R_{k}}\right)\left(R_{u, l}-\overline{R_{1}}\right)}{\sqrt{\sum_{u=1}^{m}\left(R_{u, k}-\overline{R_{u}}\right)} \sqrt[2]{\sum_{u=l}^{m}\left(R_{u, l}-\overline{R_{1}}\right)^{2}}}(2)
$$

Metode weighted average of deviation yang didapat dari dari rata- rata item yang telah dirating merupakan metode yang digunakan untuk prediksi rating pada item $\mathrm{k}$ yang telah dirating. Kemudian metode weighted average of deviasi dalam menghitung ranting dari setiap rata-rata item menggunkan persamaan 3 .

$P_{u, k}=\overline{R_{k}}+\frac{\sum_{i=1}^{n}\left(R_{u, l}-\bar{R}_{l}\right) x \operatorname{sim}(k, l)}{\sum_{i=1}^{n}|\operatorname{sim}(k, l)|}$

Dalam menghitung akurasi dari rating item pendekatan nilai mean absolute error (MAE) digunakan. Nilai MAE dihitung dengan persamaan 4 berikut:

$M A E=\frac{n x \sum_{u=1}^{N}\left|P_{u, i}-R_{u, i}\right|}{N}$

\section{HASIL DAN PEMBAHASAN}

Usulan sistem yang digunakan dapat memproses pengambilan keputusan terhadap salah satu produk. Pengambilan keputusan yang dimaksud guna untuk menentukan apakah produk tersebut masih dalam kategori popular produk dan produk yang direkomendasikan atau tidak. Tujuannya memberikan informasi kepada calon pembeli sebelum menentukan pilihannya saat ingin membeli produk-produk tersebut. Tolak ukur atau parameter dalam pemberian label satu produk menjadi popular produk dan recommended produk adalah nilai rating yang diberikan oleh pembeli saat sesudah melakukan transaksi pembelian dalam aplikasi.

Pada proses perhitungan Rating produk dengan metode Collaborative Filtering berbasis item ditujukan pada flowchart yang ditunjukkan pada Gambar 2. 


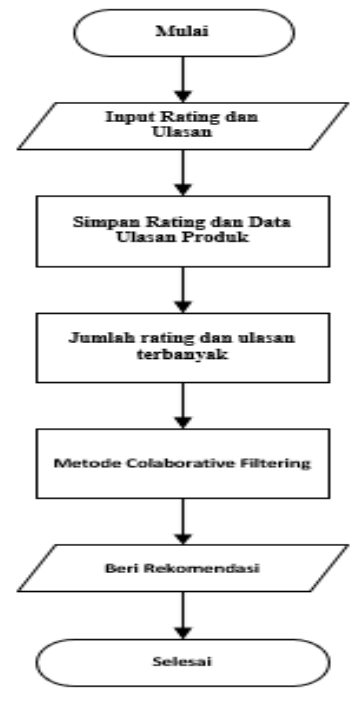

Gambar 3. Rancangan flow diagram untuk colaboratif filtering berbasis item

Pembeli memberikan rating terhadap produk yang dibeli pada aplikasi UMKM. Rating dan ulasan produk tersebut kemudian tersimpan dalam database sistem UMKM. Selanjutnya dilakukan proses perhitungan rating dan ulasan terbanyak yang telah diberikan oleh pembeli terhadap produk tersebut. Proses perhitungan dengan metode collaborative filtering terbagi dalam 2 (dua) kelas, yaitu collaborative filtering berbasis user yaitu merekomendasikan produk dengan user tertinggi dan item based collaborative filtering untuk merekomendasikan produk berdasarkan rating dan ulasan yang telah diberikan oleh pembeli[16]. Rekomendasi produk diberikan berdasarkan rating urutan tertinggi. Proses penerapan ke Metode Item Based Collaborative Filtering yaitu:

1. Produk yang dibeli diberikan nilai (berdasarkan rating)

Tabel 1. Rating Pembeli Terhadap Produk

\begin{tabular}{lllllll}
\hline $\begin{array}{l}\text { Customer Puta } \\
\text { Produk }\end{array}$ & \multicolumn{6}{c}{ Sarabati Tobaru Barakati NyiruSaloy } \\
\hline Cust 1 & - & 3 & - & 5 & 1 & 2 \\
Cust 2 & - & 5 & 3 & - & 4 & - \\
Cust 3 & 4 & - & 4 & - & - & 3 \\
Cust 4 & 3 & 5 & 2 & - & 3 & - \\
Cust 5 & - & 3 & - & 4 & 5 & - \\
Cust 6 & 5 & - & 4 & - & - & 5 \\
\hline
\end{tabular}

2. Nilai average rating yaitu jumlah nilai rating (rata-rata rating) kemudian dipangkatkan 2

Tabel 2. Jumlah rating-(rata-rata rating) per produk

\begin{tabular}{cccccccc}
\hline \multicolumn{3}{c}{ Produk Puta SarabatiTobaruBarakati Nyiru Saloy Rata-rata } \\
\multicolumn{3}{c}{ Dino } \\
\hline Cust 1 & - & 3 & - & 5 & 1 & 2 & 2.75 \\
Cust 2 & - & 5 & 3 & - & 4 & - & 4 \\
Cust 3 & 4 & - & 4 & - & - & 3 & 3.667 \\
Cust 4 & 3 & 5 & 2 & - & 3 & - & 3.25 \\
Cust 5 & - & 3 & - & 4 & 5 & - & 4 \\
Cust 6 & 5 & - & 4 & - & - & 5 & 4.667 \\
\hline
\end{tabular}

3. Mengakumulasi similarity antar item produk dengan persamaan berikut.

$\operatorname{sim}(k, l)$

$$
=\frac{\sum_{\mathrm{u}=1}^{\mathrm{m}}\left(R_{u, k}-\overline{R_{u}}\right)\left(R_{u, l}-\overline{R_{u}}\right)}{\sqrt{\sum_{u=1}^{m}\left(R_{u, k}-\overline{R_{u}}\right)} \sqrt[2]{\sum_{u=l}^{m}\left(R_{u, l}-\overline{R_{u}}\right)^{2}}}
$$

Perhitungan nilai similarity produk puta dino dengan produk sarabati :

$\operatorname{Sim}($ puta dino, sarabati $)=\frac{(3-3.25)(5-3.25)}{\sqrt{(3-3.25)^{2}} \cdot \sqrt{(5-3.25)^{2}}}$

$\operatorname{Sim}($ puta dino, sarabati $)=\frac{-0.4375}{0.25 \times 1.75}$

$\operatorname{Sim}($ puta dino, sarabati $)=-1$

Dilanjutkan dengan menghitung kesamaan nilai diperoleh seperti pada tabel 3 berikut.

Tabel 3. Hasil Similarity Antar Produk

\begin{tabular}{ccc}
\hline Produk 1 & Produk 2 & Nilai Similarity \\
\hline Puta Dino & Sarabati & -1 \\
Puta Dino & Tobaru & 0.26 \\
Puta Dino & Barakati & 0 \\
Puta Dino & nyiru & 1 \\
Puta Dino & saloy & -0.32 \\
Sarabati & Tobaru & -0.99 \\
Sarabati & Barakati & 0.24 \\
Sarabati & nyiru & -0.49 \\
Sarabati & saloy & -1 \\
Tobaru & Barakati & 0 \\
Tobaru & nyiru & 0.78 \\
Tobaru & saloy & -0.8 \\
Barakati & nyiru & -0.87 \\
Barakati & saloy & -1 \\
Nyiru & saloy & 1 \\
Puta Dino & Sarabati & -1 \\
\hline & & \\
\hline & &
\end{tabular}

Nilai yang dihasilkan oleh persamaan adjusted cosine adalah antara -1.0 hingga +1.0 . Jika nilai koefisien semakin mendekati +1 , maka hubungan antara kedua produk tersebut akan sangat kuat. Jika koefesiennya bernilai 0 , maka kedua produk tidak mempunyai hubungan (independen). Sebaliknya jika nilai yang dihasilkan -1, maka kedua produk tersebut tidak empunyai kemiripan atau tidak terekomendasi. Selanjutnya adalah mengakumulasi user terhadap nilai prediksi produk. Diperoleh bahwa nilai $>0$ digunakan sebagai nilai prediksi, karena nilai tersebut dianggap sebagai batas bawah keterhubungan antar produk. Untuk memperoleh nilai prediksi dari suatu produk yang belum di rating oleh customer, digunakan persamaan weighted sum dengan rumus sebagai berikut.

$$
P_{u, k}=\overline{R_{k}}+\frac{\sum_{i=1}^{n}\left(R_{u, l}-\bar{R}_{l}\right) x \operatorname{sim}(k, l)}{\sum_{i=1}^{n}|\operatorname{sim}(k, l)|}
$$


Pcust 1 , puta dino $=$

$(3 x-1)+(0 x 0.26)+(5 x 0)+(1 \times 1)+(2 x-0.32)$

$|-1|+|(0.26)|+|(0)|+|(1)|+|(-0.32)|$

$$
\begin{aligned}
& =\frac{-2.64}{2.58} \\
& =-1.023
\end{aligned}
$$

Hasilnya seperti pada tabel 4 berikut ini.

Tabel 4. Hasil Prediksi

\begin{tabular}{ccc}
\multicolumn{3}{c}{ Tabel 4. Hasil Prediksi } \\
\hline Customer & Produk & Prediksi \\
\hline 1 & puta dino & -1.023 \\
1 & tobaru & -1.339 \\
2 & puta dino & -0.08 \\
2 & barakati & -1.08 \\
2 & saloy & -0.82 \\
3 & sarabati & -14.42 \\
3 & barakati & -1.42 \\
3 & nyiru & 2.44 \\
4 & barakati & -0.67 \\
4 & saloy & -1.11 \\
5 & puta dino & 0.77 \\
5 & tobaru & 0.33 \\
5 & saloy & -0.48 \\
6 & sarabati & -3.75 \\
6 & barakati & -2.37 \\
6 & nyiru & 3.17 \\
\hline
\end{tabular}

Dari tabel hasil prediksi tersebut disimpulkan bahwa custumer 3 memperoleh rekomendasi produk nyiru, custumer 5 mendapatkan rekomendasi produk Puta Dino dan Tobaru, cutumer 6 mendapatkan rekomendasi produk nyiru.

Penelitian ini memperlihatkan ouput berupa aplikasi Android dashboard desa yang dapat memberikan rekomendasi produk terbaik berdasarkan rating yang diberikan oleh pelanggan sehingga menjadi referensi bagi pengelola atau penjual untuk meningkatkan kualitas produknya, Aplikasi UMKM ini membantu untuk mempermudah pelanggan atau user dalam mencari produk UMKM dan melakukan pemesanan produk UMKM desa.

Pengujian sistem dan fungsi-fungsinya terhadap aplikasi mobile dashboard Desa Cerdas. Pengujian ini menggunakan metode blackbox dan user acceptance testing (UAT), yaitu menguji pada fungsional sistem.

\begin{tabular}{|c|c|c|c|c|}
\hline No & Skenario & Tes Fungsi & Hasil & Ket. \\
\hline 1 & $\begin{array}{l}\text { Register } \\
\text { User }\end{array}$ & $\begin{array}{l}\text { Memberikan } \\
\text { data pengguna } \\
\text { untuk diproses } \\
\text { pendaftaran }\end{array}$ & Sesuai & $\begin{array}{l}\text { Halaman } \\
\text { pendaftaran } \\
\text { user sukse }\end{array}$ \\
\hline 2 & $\begin{array}{l}\text { Login } \\
\text { User }\end{array}$ & $\begin{array}{l}\text { Membantu } \\
\text { pengguna } \\
\text { dalam masuk } \\
\text { ke menu utama }\end{array}$ & Sesuai & $\begin{array}{l}\text { Ketika user } \\
\text { dan password } \\
\text { di inputkan } \\
\text { benar maka } \\
\text { form login } \\
\text { berhasil }\end{array}$ \\
\hline 3 & $\begin{array}{l}\text { Menu } \\
\text { Utama }\end{array}$ & $\begin{array}{l}\text { Menampilkan } \\
\text { menu utama } \\
\text { yang berisikan }\end{array}$ & Sesuai & $\begin{array}{l}\text { Halaman dan } \\
\text { menu utama } \\
\text { ditampilkan }\end{array}$ \\
\hline
\end{tabular}

Tabel 6. Pengujian interface Aplikasi Pelanggan
Home Product

Categories,

Cart,

Transcation

dan Account.

\begin{tabular}{|c|c|c|c|c|}
\hline No & Skenario & Tes Fungsi & Hasil & Ket. \\
\hline 1 & Login & $\begin{array}{l}\text { Menampilkan } \\
\text { halaman utama } \\
\text { system admin }\end{array}$ & sesuai & $\begin{array}{c}\text { Ketika } \\
\text { user dan } \\
\text { password } \\
\text { di inputkan } \\
\text { benar maka } \\
\text { form login } \\
\text { berhasil }\end{array}$ \\
\hline 2 & $\begin{array}{l}\text { Menu } \\
\text { admin }\end{array}$ & $\begin{array}{c}\text { Menampilkan } \\
\text { menu utama } \\
\text { admin yang } \\
\text { berisi home, } \\
\text { Data } \\
\text { konsumen, } \\
\text { rating } \\
\text { Penjualan,, } \\
\text { Produk, } \\
\text { wilayah, } \\
\text { Laporan, user } \\
\text { admin }\end{array}$ & Sesuai & $\begin{array}{c}\text { Halaman } \\
\text { menu } \\
\text { utama } \\
\text { admin } \\
\text { ditampilkan }\end{array}$ \\
\hline
\end{tabular}

Tabel 5 Pengujian interface admin

Pengujian User Acceptance Testing Pengujian ini menggunakan kuisoner dengan 25 responden untuk mengetahui tingkat pemahaman para pengguna terhadap aplikasi ini. Proses ini menggunakan tiga indikantor yaitu desain, kemudahan dan efisien. Responden akan memberikan jawaban dengan 5 (lima) pilihan jawaban yaitu Sangat Bagus (SB), Bagus (B) Netral (N), Cukup (C) dan Tidak Bagus (TB).

Tabel 6 Pengujian User Acceptance Testing

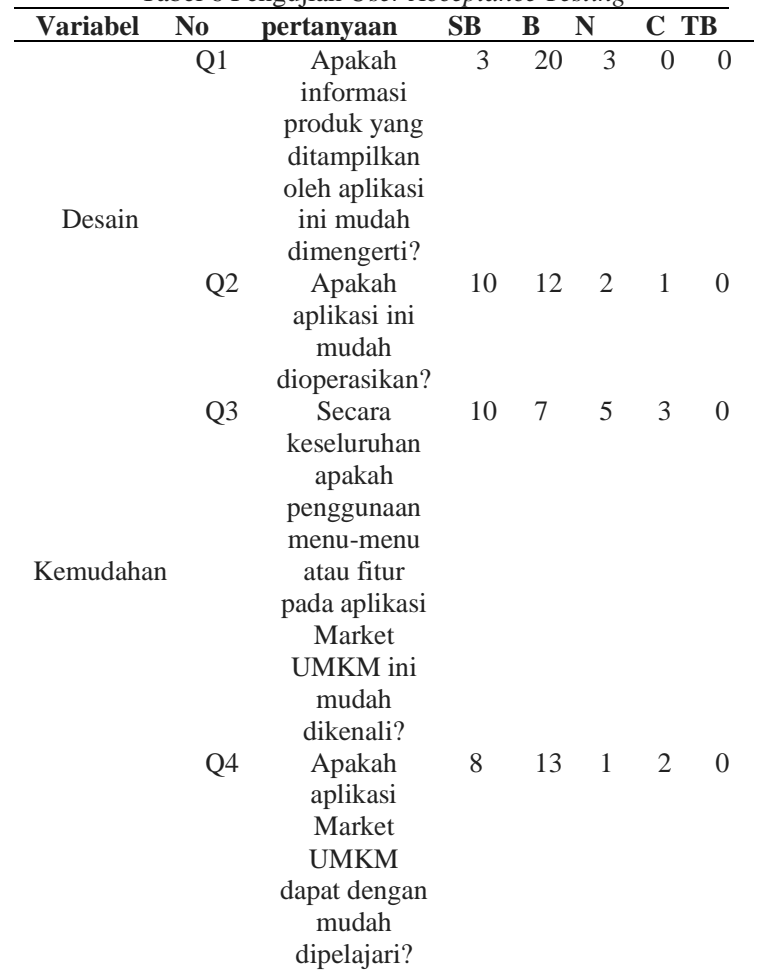




\begin{tabular}{|c|c|c|c|c|c|c|c|}
\hline & Q5 & $\begin{array}{c}\text { Apakah } \\
\text { informasi } \\
\text { aplikasi } \\
\text { mudah } \\
\text { dibaca? }\end{array}$ & 6 & 16 & 3 & 0 & 0 \\
\hline & Q6 & $\begin{array}{c}\text { Apakah } \\
\text { aplikasi } \\
\text { Market } \\
\text { UMKM ini } \\
\text { dapat } \\
\text { bermanfaat } \\
\text { bagi } \\
\text { pengguna? }\end{array}$ & 11 & 7 & 5 & 2 & 0 \\
\hline Efisien & Q7 & $\begin{array}{c}\text { Apakah } \\
\text { halaman } \\
\text { aplikasi } \\
\text { mudah } \\
\text { dicari? }\end{array}$ & 6 & 14 & 1 & 4 & 0 \\
\hline & Q8 & $\begin{array}{c}\text { Apakah } \\
\text { aplikasi } \\
\text { Market } \\
\text { UMKM ini } \\
\text { mempunyai } \\
\text { fungsi sesuai } \\
\text { dengan yang } \\
\text { diharapkan? }\end{array}$ & 11 & 5 & 5 & 4 & 0 \\
\hline
\end{tabular}

Berdasarkan table 6 diatas hasil dari kuisoner telah didapatkan selanjutnya dianalisa untuk menentukan presentase tingkat keberhasilan aplikasi ini. Proses pengambilan data kuisoner dilakukan dengan cara membagikan 25 kuisoner kepadapa mahasiswa, dosen dan masyarakat yang merupakan pengguna aplikasi tersebut. Kemudian 25 data kuisoner yang telah terisi dilakukan perhitungan menggunakan Microsoft Excel untuk menentukan point dari opsi jawaban yang telah yang dipilih. Opsi jawaban yang telah memiliki poin dikategorikan berdasarkan 5 (lima) pilihan yaitu Sangat Bagus (SB), Bagus (B), Netral (N), Cukup (C) dan Tidak Bagus (TB). Setelah itu dilakukan perhitugan dengan cara mengalikan setiap poin jawaban dengan bobot yang sudah ditentukan sesuai dengan bobot nilai jawaban.

\begin{tabular}{lc}
\multicolumn{2}{c}{ Tabel 7 Bobot Nilai Jawaban } \\
\hline Jawaban & Bobot \\
\hline Sangat Bagus & 5 \\
Bagus & 4 \\
Netral & 3 \\
Cukup & 2 \\
Tidak cukup & 1 \\
\hline
\end{tabular}

Hasilnya ditujukan pada table 8 berikut.

Tabel 8 Hasil Pengujian User Acceptance Testing

\begin{tabular}{|c|c|c|c|c|c|c|c|}
\hline Variabel & No & Pertanyaan & SB & B & $\mathrm{N}$ & $\mathrm{C}$ & TB \\
\hline Desain & Q1 & $\begin{array}{l}\text { Apakah informasi } \\
\text { produk yang } \\
\text { tampilkan oleh } \\
\text { aplikasi ini } \\
\text { mudah } \\
\text { dimengerti? }\end{array}$ & 3 & 20 & 3 & 0 & 0 \\
\hline & Q2 & $\begin{array}{l}\text { Apakah aplikasi } \\
\text { ini mudah } \\
\text { dioperasikan? }\end{array}$ & 10 & 12 & 2 & 1 & 0 \\
\hline $\begin{array}{l}\text { Kemu } \\
\text { dahan }\end{array}$ & Q3 & $\begin{array}{c}\text { Secara } \\
\text { keseluruhan } \\
\text { apakah } \\
\text { penggunaan }\end{array}$ & 10 & 7 & 5 & 3 & 0 \\
\hline
\end{tabular}

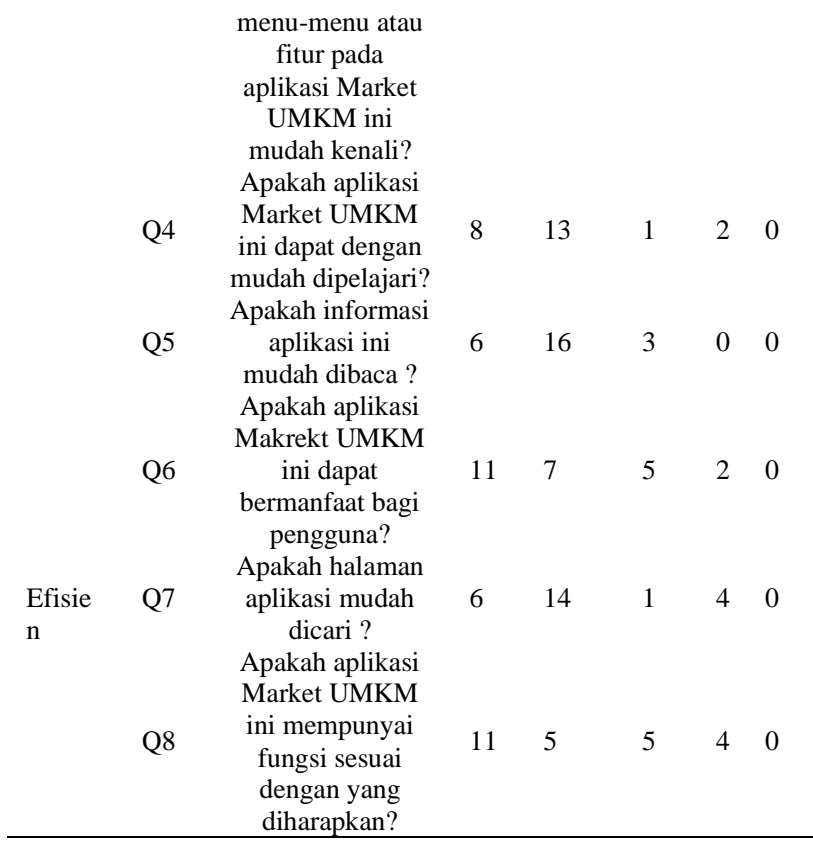

Hasil analisa pertanyaan pada tabel 4.8 dari hasil pengujian user acceptance testing adalah sebagai berikut :

a. Analisa pertanyaan Q1

Pada pertanyaan pertama bahwa 25 responden untuk pertanyaan Q1 adalah 104. Average nya adalah $\frac{104}{25}=4,16$. Kemudian menghitung persenya $\frac{4,16}{5} \times 100=83,2 \%$

b. Analisa pertanyaan Q2

Pada pertanyaan kedua bahwa 25 responden untuk pertanyaan Q2 adalah 106. Average nya adalah adalah $\frac{106}{25}=4,16$. Pada pertanyaan ke enam bahwa 25 responden untuk pertanyaan $\frac{4,24}{5} \times 100=84,8 \%$

c. Analisa pertanyaan Q3

Pada pertanyaan ketiga bahwa 25 responden untuk pertanyaan Q3 adalah 99. Average nya adalah adalah $\frac{99}{25}=3,96$. Pada pertanyaan ke enam bahwa 25 responden untuk pertanyaan $\frac{3,96}{5} \times 100=79,2 \%$

d. Analisa pertanyaan Q4

Pada pertanyaan ke empat bahwa 25 responden untuk pertanyaan Q4 adalah 99. Average nya adalah adalah $\frac{99}{25}=3,96$. Pada pertanyaan ke enam bahwa 25 responden untuk pertanyaan $\frac{3,96}{5} \times 100=79,2 \%$

e. Analisa pertanyaan Q3

Pada pertanyaan ke lima bahwa 25 responden untuk pertanyaan Q3 adalah 99. Average nya adalah adalah $\frac{99}{25}=3,96$. Presentase nilainya adalah $\frac{3,96}{5} \times 100=79,2 \%$

f. Analisa pertanyaan Q4

Pada pertanyaan ke enam bahwa 25 responden untuk pertanyaan Q4 adalah 99. Average nya 
adalah adalah $\frac{99}{25}=3,96$. Pada pertanyaan ke enam bahwa 25 responden untuk pertanyaan $\frac{3,96}{5} \times 100=79,2 \%$

g. Analisa pertanyaan Q6

Pada pertanyaan ke tujuh bahwa 25 responden untuk pertanyaan 25 responden untuk pertanyaan Q6 adalah 102. Average nya adalah adalah $\frac{102}{25}=$ 3,96 . Pada pertanyaan ke enam bahwa 25 responden untuk pertanyaan $\frac{3,96}{5} \times 100=79,2 \%$

h. Analisa pertanyaan Q7

Pada pertanyaan ini terhadap 25 responden untuk pertanyaan Q7 adalah 97. Average nya adalah $\frac{97}{25}=3,88$. Pada pertanyaan ke enam bahwa 25 responden untuk pertanyaan $\frac{3,88}{5} \times$ $100=77,6 \%$

i. Analisa pertanyaan Q8

Pada pertanyaan ini terhadap 25 responden untuk pertanyaan Q8 adalah 98. Average nya adalah $\frac{98}{25}=3,92$. Pada pertanyaan ke enam bahwa 25 responden untuk pertanyaan $\frac{3,92}{5} \times$ $100=78,4$

Berdasarkan tabel 8 dari hasil pengujian kuesioner yang telah dijumlahkan berdasarkan opsi jawaban dari 25 orang responden lalu diambil nilai rata-rata dan hasil analisa delapan pertanyaan dari pengolahan tersebut didapatkan hasil presentasi dari ketiga indikator. Dari ketiga indikator tersebut memiliki Presentase berbeda-beda, pertama dari segi desain $84,8 \%$ responden menjawab sangat bagus tampilan yang ada pada aplikasi UMKM Desa Maregam, kemudian dari segi kemudahan 79,2\% responden menjawab bagus dengan penggunaan aplikasi UMKM Desa Maregam ini dapat memudahkan proses pembelian produk UMKM dimana saja dan kapan saja, dan dari segi efisien $77,6 \%$ responden menjawab cukup dengan adanya aplikasi ini dapat memberikan manfaat bagi masyarakat yang ingin mengetahui informasi UMKM Desa Maregam.

Dari hasil akhir pengolahan kuesioner diatas, kemudian disajikan dalam bentuk grafik seperti berikut ini :

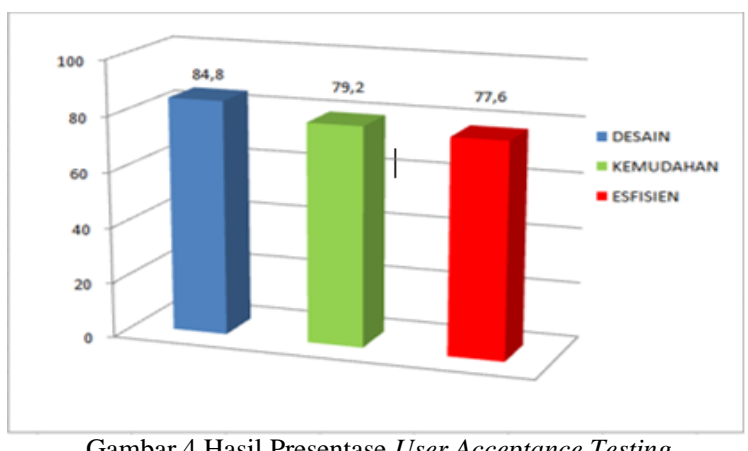

Gambar 4 Hasil Presentase User Acceptance Testing

\section{KESIMPULAN}

Aplikasi ini mampu memberikan rekomendasi produk terbaik berdasarkan rating yang diberikan oleh pelanggan sehingga menjadi referensi bagi pengelola atau penjual untuk meningkatkan kualitas produknya, Aplikasi UMKM ini membantu untuk mempermudah pelanggan atau user dalam mencari produk UMKM dan melakukan pemesanan produk UMKM desa Maregam. Dari hasil penhujian user accetance testing (UAT), black box testing, dan perhitungan rekomendasi secara manual menggunakan microsoft excel memperoleh presentasi sukses 100\%, Aplikasi ini menggunakan metode colaborative filltering dengan memberikan hasil rekomendasi produk berdasarkan rating atau penilaian dan ulasan dari pelanggan pada produk yang telah dibeli. Proses penerapan metode colaborative filltering dibagi dalam 2 (dua) kelas yaitu metode user based colaborative filtering untuk merekomendasikan produk dengan jumlah produk yang dilihat dari urutan tertinggi dan item based colaborative filltering untuk merekomendasikan produk berdasarkan rating dan ulasan yang telah diberikan oleh pembeli.

\section{DAFTAR PUSTAKA}

[1] Masterplandesa., 24 April 2020. "Awal Pengembangan Desa Menuju Desa Cerdas".

[2] A. D. Santoso and U. Sriwijaya. september 2019-2020. Desa Cerdas: Transformasi Kebijakan dan Pembangunan Desa Merespon Era Revolusi Industri 4.0

[3] D. Herdiana., 2019 "Pengembangan Konsep Smart Village Bagi Desa-Desa di Indonesia (Developing the Smart Village Concept for Indonesian Villages)," J. IPTEKKOM J. Ilmu Pengetah. Teknol. Inf., vol. 21, no. 1, p. 1,2019, doi: 10.33164/iptekkom.21.1.2019.1-16.

[4] N. Marisa., 2018 "Ketimpangan Pembangunan Desa TertinggaL (Studi Pada Pekon Atar Kuwau dan Pekon Argomulyo)," pp. 42-43, 2018.

[5] Kotatikep, tahun 2019 "Sistem Informasi Manajemen pada PT . POS Indonesia," no. 165100113 ,

[6] J. Oliver., 2017 "No Title No Title,” J. Chem. Inf. Model., vol. 53, no. 9, pp. 1689-1699,2017, doi: 10.1017/CBO9781107415324.004.

[7] M. Gunawan, 2018 "Rancang Bangun Sistem Rekomendasi e-Commerce pada Distro IT Menggunakan Item-Based Collaborative Filtering," Perpust. Politek. Negeri Jakarta, vol. 1, no. 1, 2018.

[8] D. Trisnawarman, Z. Rusdi, P. Studi, S. Informasi, 2018 F. T. Informasi, and U. Tarumanagara, "Desain Dashboard Untuk Pendukung," vol. 1, pp. 14-22, 2018.

[9] R. Ismayanti et al., 2020 "Sistem Pakar Rekomendasi Obat Antidiabetika Oral Dan 
Expert Systems for Oral Antidiabetic Recommendation and Their," vol. 3, no. 3, pp. 125-130, 2020, doi: 10.33387/jiko.

[10] E. Jayadi, B. Mulyawan, and M. Dolok, 2020 "Implementasi Metode Collaborative Filtering Untuk Analisis Data Belanja Konsumen Berbasis Website ( Studi Kasus Restoran Mykitchen )," pp. 57-61, 2020, [Online].Available:

https://journal.untar.ac.id/index.php/jiksi/article /view/11559/7232.

[11] F. Tempola., A. Arief., dan M. Muhammad, 2017 "Combination of case-based reasoning and nearest neighbour for recommendation of volcano status." 2nd International conferences on Information Technology, Information Systems and Electrical Engineering (ICITISEE). pp. 348-352

[12] S. Bayar, 2018 "perbandingan sistem rekomendasi film metode user-based dan itembased collaborative filtering," 2018.

[13] R. R. Polii et al., 2017 "Analisa dan Perancangan Sistem Informasi Desa Berbasis Web Model Government-to-Citizen," J. Tek. Inform. Univ. Sam Ratulangi, vol. 12, no. 1, 2017.

[14] Y. Setiawan, A. Nurwanto, and A. Erlansari, 2019 "Implementasi Item Based Collaborative Filtering Dalam Pemberian Rekomendasi Agenda Wisata Berbasis Android," Pseudocode, vol. 6, no. 1, pp. 13-20, 2019, doi: 10.33369/pseudocode.6.1.13-20.

[15] A. Pamuji., 2017 "Sistem Rekomendasi Kredit Perumahan Rakyat Dengan Menggunakan Metode Collaborative Filtering," Fakt. Exacta, vol. 10, no. 1, pp. 1-9.

[16] H. D. Februariyanti., 2021 "Implementasi Metode Collaborative Filtering Untuk Sistem Diterbitkan :," vol. IX, no. I, pp. 43-50, 2021. 